\title{
Beitrag zur Kenntniss der Euglena sanguinea.
}

Von

F. Kutscher.

(Aus dem physiologischen Institut in Marburg.)

(Der Redaction zugegangen am 2. December 1897.)

Im vorigen Sommer stellte Herr Professor Dr. Korschelt dem physiologischen Institut ein Gläschen mit einer Flagellaten- . cultur zu, welche von Herrn Professor Dr. O. Zacharias in Ploen gesammelt war. Bei der Bearbeitung dieses Produkts habe ich folgende Resultate erhalten.

Die mikroskopische Untersuchung zeigte, dass die Cultur zum grössten Theil aus tiefrothbraun gefärbten Flagellaten bestand. Beigemengt waren denselben wenige grüne Flagellaten, grüne Algenfäden, farblose Bacterien und reichliche Mengen nicht organisirter Substanz. Von der letzteren versuchte ich die Flagellaten möglichst durch Sedimentirung zu befreien. Darauf wurden dieselben zunächst mit kaltem, dann mit siedendem absoluten Alkohol extrahirt. Bei dieser Behandlung gaben sie ihren Farbstoff an den Alkohol ab. Der Alkohol wurde auf dem Wasserbade bei mässiger Temperatur concentrirt. Bei seinem Erkalten schied sich der Farbstoff der rothen Flagellaten in kleinen, granatrothen Krystalldrusen an den Wänden der Abdampfschale aus. Die Krystalle wurden gesammelt und noch einige Male aus heissem Alkohol umkrystallisirt. Sie schieden sich dabei meist wieder in kleinen Krystallaggregaten aus, die aus wetzsteinförmigen, der Harnsäure ähnlichen Einzelindividuen zusammengesetzt waren. Nur selten erhielt ich einzelne gut ausgebildete Krystalle von Oktaederform. Unter dem Mikroskope suchte ich mir die am 
besten ausgebildeten Krystalle aus und benutzte diese zur Schmelzpunktbestimmung. Bei drei Versuchen erhielt ich vollkommen übereinstimmende Resultate, nämlich ein Zusammensintern bei $103^{\circ}$ C. und Schmelzen bei $105^{\circ}$ C. Der Farbstoff schien durch das Schmelzen eine Zersetzung nicht erfahren zu haben, denn die Schmelzen lösten sich leicht in heissem Alkohol und krystallisirten aus ihren Lösungen beim Verdunsten des Alkohols wieder aus.

Weiter prüfte ich das Verhalten der Krystalle oder ihrer alkoholischen Lösungen gegenüber einigen chemischen Reagentien. Dabei ergab sich, dass sie durch $50 \%$ Schwefelsäure blau, durch $50 \%$ Salpetersäure grün gefärbt wurden. Zwölfprocentige Salzsäure vertiefte in den gelbrothen alkoholischen Lösungen nur das Roth des Farbentones. Starke Ammoniakflüssigkeit, Kali und Natronlauge änderten die Farblösungen scheinbar nicht.

Endlich suchte ich das Spectrum des von mir isolirten Farbstoffes festzustellen. Ich benutzte hierzu einen Spectralapparat, dessen Scala so eingestellt war, dass sich Theilstrich 50 der Scala genau mit der Linie D und 70 mit der Linie $E$ des Spectrums deckte. Zur Untersuchung verwandte ich eine gesättigte, ätherische Lösung des Farbstoffes. Dieselbe löschte vollkommen das Ende des Spectrums aus. Die Absorption schnitt nicht ganz scharf mit Theilstrich $62 \mathrm{im}$ Grün ab. Nach vorsichtiger, allmählicher Verdünnung der Farblösung trat langsam eine Aufhellung der Absorptionszone, vom Grün beginnend, ein. Zur Bildung charakteristischer Absorptionsstreifen kam es dabei nicht.

Ein Vergleich des obigen Farbstoffes mit dem von Wit$\left.\mathrm{tich}^{1}\right)$ und Bütschli ${ }^{2}$ ) aus der Euglena sanguinea isolirten zeigte, dass derselbe der gleiche ist. Der Euglenenfarbstoff leitet mich zu dem rothen Pigment der Schwefelbacterien, mit dem er nach Bütschli wegen der grossen Uebereinstimmung der chemischen Reactionen identisch sein soll. Wäre

1) Wittich, Virchow's Archiv, Bd. 27, S. 573.

2) Bütschli, Bronns Classen und Ordnungen des Thierreichs. Abth. II, S. 733, und Ueber den Bau der Bacterien und verwandter Organismen, S. 9 und 10. 
dies wirklich der Fall, müsste die Schlussfolgerung gestattet sein, dass das Spectrum des Euglenenfarbstoffes und des Bacteriopurpurins die gleichen sind. Dem ist jedoch nicht so, denn die von R. Lankester ${ }^{1}$ ) und Engelmann) für das Bacteriopurpurin aufgestellten Spectra und das des Euglenenfarbstoffes differiren ganz ausserordentlich. Nun decken sich allerdings die Spectra Lankester's und Engelmann's auch nicht, und man hat versucht, die Abweichungen in denselben durch Verunreinigungen des Bacteriopurpurins zu erklären. Meiner Ansicht nach mit Unrecht. Vielmehr scheint es mir, entgegen den Ausführungen Winogradsky's, ${ }^{3}$ ) bei den rothen Schwefelbacterien sich um eine Reihe verschiedener Farbstoffe zu handeln, die wir zur Zeit noch nicht chemisch, wohl aber spectroskopisch unterscheiden können. $\mathrm{Zu}$ dieser Behauptung veranlasst mich nachstehende Beobachtung. Vom hiesigen botanischen Institut waren mir freundlicher Weise grössere Mengen einer kleinen Schwefelbacterie (es handelte sich um Spirillen von der Grösse des Spirillum Esmarch) zur Verfügung gestellt. Der rothe Farbstoff der Bacterien liess sich ohne besondere Schwierigkeit in granatrothen, sechsseitigen Blättchen gewinnen. Die chemischen Reactionen der kleinen Krystalle waren die gleichen wie die des Euglenenfarbstoffes, das Spectrum dagegen folgendes: Bei Einstellung des Theilstriches 50 der Scala auf die Linie D erschien zwischen Theilstrich 77-85 im Grün ein Absorptionsstreifen, ein zweiter zwischen Theilstrich 92-100 im Blau und ein dritter zwischen Theilstrich 115-120 ebenfalls im Blau. Das eben geschilderte Spectrum entfernt sich gleichfalls weit von dem Spectrum Lankester's und Engelmann's. Da das von mir benutzte Bacteropurpurin ein reines, krystallisirtes war, lässt sich die Differenz in den Spectren hier nicht auf eine Verunreinigung zurückführen, sondern nur durch meine obige Annahme erklären.

1) R. Lankester, Quarterly Journal of Mikroskop. Science. Vol. 13. New Ser., S. 425

2) Engelmann, Pflügers Archiv. Bd. 30, S. 95.

3) Winogradsky, Beiträge zur Morphologie und Physiologie der Bacterien, Heft 1, S. 46 . 
Die mit Alkohol behandelten Euglenen wurden noch mit Aether erschöpft und über Schwefelsäure getrocknet, ihre Masse betrug etwas über 0,6 gr. Unter dem Mikroskop zeigten sich die Flagellaten jetzt farblos, aber vollgestopft mit runden, farblosen Körnern verschiedener Grösse. Die Untingirbarkeit der Körner durch Farbstoffe und Jod, ihre Widerstandsfähigkeit gegen verdünnte Säuren und Fermente und ihre Löslichkeit in starker Kalilauge kennzeichneten sie als Paramylumkörner. Ich möchte hier eine bisher nicht bekannte Reaction der Paramylumkörner erwähnen. Es ist das ihre Löslichkeit in Formalin. Ich beobachtete dieselbe, als ich unter dem Mikroskop zu den trockenen Euglenen seitlich einen Tropfen Formalin zufliessen liess. Zunächst schien dasselbe ohne Einwirkung zu bleiben, nach ca. 30 Minuten zeigten sich jedoch die Paramylumkörner etwas gequollen. Danach riss die Membran der Euglenen und aus der Rissstelle drängten sich die Paramylumkörner, die ihre rundliche Gestalt in eine stäbchenförmige, häufig sichelartig gekrümmte änderten. Schliesslich trat im Laufe von 1-2 Stunden eine völlige Auflösung der Körner ein.

Da der Reichthum der Flagellaten an Paramylumkörnern ein sehr grosser war und mir ein ziemlich reines Material zur Verfügung stand, versuchte ich eine quantitative Bestimmung des von den Euglenen eingeschlossenen Paramylums. Ich benutzte hierzu 0,4 gr. Euglenen, gewann aus denselben nach dem Verfahren von Gottlieb ${ }^{1}$ ) das Paramylum, trocknete es bei $100^{\circ} \mathrm{C}$. bis zur Gewichtsconstanz und brachte es zur Wägung. Es betrug 0,201 gr. Demnach waren im vorliegenden Falle zum mindesten 50,25\% der Euglenensubstanz durch Paramylum gebildet worden.

Das gewonnene Paramylum löste ich in einigen Cubikcentimetern warmer concentrirter Salzsäure, verdünnte dieselbe darauf und erhitzte 15 Minuten am Rückfluss-Kühler. Das Reactionsprodukt reduzirte Kupferoxyd sehr stark und vergährte mit Hefe. Den reduzirenden, gährungsfähigen Körper näher $\mathrm{zu}$ bestimmen, ist mir leider bisher nicht gelungen. -

1) Siehe Gottlieb, Ann. Chem. Pharm. Bd. 75, S. 50. 